\title{
Van geschreven naar gesproken taal
}

\author{
Ad Foolen en Ton van der Wouden
}

Het commentaar van Liesbeth Degand op onze bijdrage geeft ons aanleiding om nog eens te reflecteren op hoe we te werk zijn gegaan bij onze speurtocht naar pragmatische partikels in de rechterperiferie.

Allereerst iets over onze insteek. Degand constateert in de openingszin van haar reactie dat we nog steeds niet weten waartoe de rechterperiferie dient. Dat zijn we geheel met haar eens, maar dat was ook niet de centrale vraag van ons artikel. Onze vraagstelling was primair lineair syntactisch, we wilden een poging doen "om het topologische beeld van laatste zinsplaats en uitloop en de observatie dat het Nederlands zinsfinale partikels kent, met elkaar te verbinden." In het begin dachten we nog dat onze voornaamste taak eruit zou bestaan er achter te komen of de partikels nu op de laatste zinsplaats of in de uitloop stonden, maar allengs zijn we ze posities daaromheen gaan toewijzen, zonder die posities overigens werkelijk theoretisch te funderen - maar daar is het ook exploratief onderzoek voor. De vraag naar de functie van de rechterperiferie en vooral dan van de partikels die daar optreden, hebben we slechts af en toe aangestipt. In haar eigen bijdrage plaatst Degand de functionele vraag juist op de voorgrond. Ze laat overtuigend zien dat voor antwoorden op die vraag uitingen in hun conversationele context bekeken moeten worden. Beurtwisseling, intersubjectiviteit en metadiscursiviteit blijken functionele categorieën die in ieder geval voor de analyse van dus in de rechterperiferie bruikbaar zijn.

In de eerste alinea van haar reactie wijst Degand er vervolgens op dat we naast corpusvoorbeelden uit het CGN ook geconstrueerde voorbeelden gebruikt hebben en dat we aan kwantificering niet toegekomen zijn. "Geconstrueerde voorbeelden" heeft in deze corpusgerichte tijd al gauw een kritische bijklank, maar misschien is het niet zo bedoeld. Onze geconstrueerde voorbeelden waren vooral varianten op CGN-voorbeelden om te testen of alternatieve plaatsingen ook mogelijk waren. We moesten vaststellen dat intuïties op dit punt niet gemakkelijk helder te krijgen zijn. Aanvullend corpusonderzoek zal hopelijk nieuwe inzichten opleveren, maar om een goed beeld te krijgen van met name zeldzame, maar mogelijke volgordes zijn ook omvangrijke corpora vaak niet toereikend. Met andere woorden, intuïties en geconstrueerde voorbeelden zouden we niet in de ban willen doen.

In de tweede alinea van haar reactie maakt Degand een meer theoretisch gericht punt. Ze stelt vast dat we "er zonder stilstaan vanuit gaan dat de traditionele grammatica, zoals die in de ANS uiteengezet wordt, zonder meer van toepassing is op gesproken taal". In moderne politiek taalgebruik zouden we kunnen zeggen dat we "ons niet helemaal herkennen in deze karakterisering". In par. 3 hebben we wel stilgestaan bij cartografische, constructionele en multifactoriële benaderingen, maar geen daarvan leverde een direct toepasbaar kader op. We zijn toen inderdaad teruggevallen op de min of meer traditionele, primair op schrijftaal gebaseerde, grammaticale beschrijvingen van het Nederlands, zoals aangereikt in de ANS en in structuralistische en generatieve studies. Zonder veel uitleg hebben we vervolgens de voor de lezers van Nederlandse Taalkunde vertrouwde woordsoortenonderscheidingen en topologische posities gebruikt.

Met betrekking tot de theorievorming over de grammatica van gesproken taal merkt Degand op: "[a]nders dan voor het Franse 'grammaire de l'oral' (...) bestaat er, bij mijn weten, geen grammaticale traditie van het gesproken Nederlands." We delen die observatie. We hebben wel naar Uijlings (1956) verwezen en we kunnen nog toevoegen dat bij degenen 
die zo'n 10 jaar geleden voor de taak stonden om het CGN te annoteren al gauw duidelijk werd dat men onder meer tegen "discourse-structuren" aanliep (zie hfst. 5 in Hoekstra et al. 2003) waarvoor aparte tags ingevoerd moesten worden. Maar daarmee is er inderdaad nog geen traditie.

We zijn zelf meer vertrouwd met de Duitse dan met de Franse taalkunde en kunnen van daaruit toevoegen dat de situatie ook voor het Duits gunstiger lijkt te zijn dan voor het Nederlands. Een sterke getuige daarvan is de Duden Grammatik, die vanaf de zevende editie (2005) een slothoofdstuk Gesprochene Sprache bevat waaruit duidelijk het besef spreekt dat het begrippenapparaat van de traditionele grammatica niet eenvoudigweg op gesproken taal toegepast kan worden. Schneider (2011) betoogt in zijn commentaar op dit hoofdstuk uit de Duden dat in een volgende versie het aspect van 'on line processing' een nog sterkere rol moeten spelen. Naar zijn mening komt men niet om de "Medialität" van taalgebruik heen: de productie- en verdere gebruikscontext heeft zijn weerslag op structuren, die laatste moeten daarom (ook) contextgebonden bestudeerd worden.

Dit punt van Schneider sluit aan bij wat Degand opmerkt naar aanleiding van haar eigen recente onderzoek, namelijk dat bij partikelgebruik de situationele context een belangrijke rol lijkt te spelen. Wij hebben ons onderzoek gericht op gesproken taal maar het lijkt er nu op dat ook dat niet specifiek genoeg is. Degand heeft in haar eigen bijdrage het materiaal verder ingeperkt tot het Nederlandstalige deel van het CGN en daarbinnen weer tot het teksttype van spontane conversaties. In haar reactie vermeldt ze dat ze inmiddels aanleiding ziet om nog specifieker te zijn. Ze verwijst naar haar onderzoek met Geertje van Bergen waaruit blijkt dat zowel frequentie als functie van partikels als dan, dus, toch en eigenlijk in spontane en chatconversatie verschilt, en ze heeft ook eerste aanwijzingen voor leeftijdsgebonden verschillen. We hebben in onze voetnoot 1 ook al nadrukkelijk op regionale verschillen gewezen en we kunnen daar nu nog aan toevoegen dat in scriptieonderzoek gebleken is dat het gebruik van specifieke partikels ook naar opleiding, leeftijd en sekse kan variëren (Valstar 2011) en dat er ook etnolectische variatie is (Schokkin 2011). Gebruiksfrequentie, positie en functie van pragmatische partikels lijken aan behoorlijk wat mediale, situationele en sociale variatie onderhevig te zijn (vgl. Foolen 2011). Deze constatering kan tegelijk als onderzoeksagenda opgevat worden.

We twijfelen er niet aan dat de in vergelijking met het Frans en Duits gesignaleerde achterstand in het onderzoek van gesproken taal voor het Nederlands de komende jaren ingehaald zal worden. Het besef dat dat nodig is, is er (vgl. Van der Wouden 2010). Op dit moment is de Neerlandistiek evenwel nog niet ver genoeg om een substantieel hoofdstuk 'gesproken taal' aan de ANS te kunnen toevoegen. Dat in zo'n hoofdstuk de rechter- en evenzo de linkerperiferie flink wat ruimte toegewezen zullen moeten krijgen, is dankzij de Dagen van de Nederlandse Zinsbouw van 2009 en 2010 echter wel duidelijk geworden, toch?

Duden (2005). Band 4: Die Grammatik. 7., völlig neu überarbeitete und erweiterte Auflage. Mannheim: Dudenverlag.

Foolen, Ad (2011). Pragmatic markers in a sociopragmatic perspective. In: Gisle Andersen \& Karin Aijmer (red.), Pragmatics of Society (Handbook of Pragmatics Vol. 5). Berlijn: de Gruyter Mouton, 215-240.

Hoekstra, Heleen, Michael Moortgat, Machteld Schouppe, Bram Renmans, Ineke Schuurman en Ton van der Wouden (2003). CGN syntactische annotatie. 
Geraadpleegd oktober 2011 via

http://www.tst.inl.nl/cgndocs/doc_Dutch/topics/annot/syntax/syn_prot.pdf

Schneider, Jan Georg (2011). Hat die gesprochene Sprache eine eigene Grammatik? Grundsätzliche Überlegungen zum Status gesprochensprachlicher Konstruktionen und zur Kategorie „gesprochenes Standarddeutsch“. Zeitschrift für Germanistische Linguistik 39,165-87.

Schokkin, Gerda H. (2011). 'Ja toch?' On the role of discourse markers and other linguistic means in the Construction of identity by adolescents from Amsterdam. (Lincom Studies in Sociolinguistics 11). München: Lincom.

Valstar, Debbie (2011). Gewoon echt gewoon, zeg maar. De pragmatische markeerder gewoon en de relatie ervan met zeg maar en echt. Masterscriptie Nederlandse Taal en Cultuur, Universiteit Leiden.

Wouden, Ton van der (2010). Over de Nederlandse spreektaal. Lezing IVG, Warschau 2010, onder review. 